\title{
The dynamics of leadership
}

\author{
C J A Vos \\ (University of Pretoria)
}

\section{ABSTRACT}

\section{The dynamics of leadership}

This article reflects on the need for dynamic leadership. An organisation's functionality is dependent on the intellectual, emotional and physical energy which the people involved in the organisation are willing to contribute. The process of energy release is determined mainly by two concepts: vision and mission. A vision is inextricably linked to a strategy. Leadership plays an essential part in the realisation of an organisation's vision and mission. In this article different leadership models are discussed. Autocratic leadership is critically analysed. Dynamic leadership, which encompasses inspirational and imaginative leadership is discussed. The community of faith and society both have a life-long need for inspirational leadership.

\section{THE NECESSITY FOR LEADERSHIP}

An organisation's functionality is dependent on the intellectual, emotional and physical energy which the people involved in the organisation are willing to contribute. The process of energy release is determined mainly by two concepts: vision and mission (Garratt 2000:68-70). Vision refers to a picture with some implicit or explicit commentary on why people should strive to create that future (Kotter 1996:68). A vision is an image of what the organisation will be like in future if it wants to fulfil the purpose for which it was established. It is the vision that dictates the general pace of change for the future. It is a dream which inspires and motivates people in and around the organisation to achieve the goals of the organisation, even if the initial steps are personally painful. Through this process a vision creates a channel for people's energy and aspirations. A vision helps to co-ordinate the actions of different people (Kotter 1996:68-75). A vision is inextricably linked to a strategy (Garratt 2000:86-93). The strategic process focuses on the integration, riskassessment, and balanced decision-making processes at the centre of the organisation's learning (Garratt 2000:80). Strategy provides both a logic and a first level of detail to show how a vision can be accomplished (Kotter 1996:71). It is not sufficient to create a vision: the vision also has to be communicated so that it becomes an organisation's way of life. 
A mission is a more readily attainable goal or aim. A mission can be defined for a shorter or longer period. It also has measurable outcomes. A mission is essentially an operational learning concept.

Leadership plays an essential part in the realisation of an organisation's vision and mission. Through dynamic leadership, policy is carried outwards, strategic actions are directed inwards and the goals of the organisation are effectively operationalised. Leadership defines what the future should look like, aligns people with that vision, and inspires them to make it happen despite the obstacles (Kotter 1996:25).

In our time there is a shortage of and a need for natural inspirational leaders. The way in which leadership is exercised has a major influence on the vitality of an organisation. Leadership is the most important means of initiating change. What I understand by the function of leadership is practising forms of behaviour that will help the group to achieve the desired results (Remmerswaal 1975:123). To express this in concrete terms, the following examples of actions that would help the group are considered (Hendriks 1990:55; Kotter 1996:55-57, 61-65, 162163:

- establishing the goals of the group;

- helping the group set about achieving the goals;

- improving interaction between the members of the group;

- reinforcing group cohesion;

- making resources available ;

- establishing trust.

Leadership as a function proceeds, not only from those people who are specially appointed as leaders, but also from other people. Anyone who is part of a group, influences the other members.

\section{LEADERSHIP MODELS AND STYLES}

Models slot into certain structures. Models require particular structures. Styles focus on actions. Styles are the action component of models. The implication of this is that models and actions can be distinguished, but not separated. For this reason we shall deal with models and styles together.

\subsection{Inspirational leadership}

Terms like "inspirational leadership", "charismatic leadership" and "visionary leadership" are in fact synonyms (Stoffels 1999:67). One could add "co-operative leadership". The term "charismatic leadership" has a magical sound, is associated with a particular person, and depends 
on exceptional gifts. Max Weber (Eisenstadt 1968) also ascribes this type of leadership, besides the other two which he distinguishes (depending respectively on inherited authority and democratic choice) to personal ability: "a certain quality of an individual's personality by virtue of which he is set apart from ordinary men and treated as endowed with superhuman or at least exceptional powers or qualities". Charismatic leadership is not, however, a phenomenon which depends solely on exceptional personality traits (Van der Lans 1999:94). Exceptional personality traits do obviously play a major part in this type of leadership, but charismatic leadership is also dependent on recognition by subordinates and followers.

Historical-sociological studies have proved satisfactorily that a charismatic interaction between leader and followers usually occurs under specific circumstances (Van der Lans 1999:94). There is a special need for charismatic leadership in a situation of radical social change, when values and opinions are being reviewed (Barnes 1978). This was the case in South Africa, for example, after the first democratic general election when Nelson Mandela played the role of a charismatic president with distinction. Leaving aside inborn personal qualities, charismatic leadership can also be learned and inculcated through certain attitudes and actions (Van der Lans 1999:94).

The concept "inspirational leadership" describes dynamic leadership well. The word "inspiration" belongs to the semantic domain of the influence of creative power - thoughts, ideas which proceed from a creative urge, the will to do things, awakening. Leadership means influencing followers in order to achieve a goal (Bryman 1992). Leadership is a means of giving form to inspiration, making it visible and transmitting it (Zondag 1999:54). Inspirational leaders generate enthusiasm by their vision, stimulate their followers to outstanding achievements, create self-confidence, succeed in getting other people to surpass themselves and motivate their colleagues from within. In inspirational leadership the bond between leaders and followers has a personal character (Den Hartog, Koopman \& Van Muijen 1997).

Inspirational leadership, which can also be termed transformational leadership, can be contrasted with impersonal or transactional leadership (Bass 1985; Andriessen \& Drenth 1997). With impersonal leaders the relationship between leaders and followers is based on exchange, give and take. Followers perform certain functions and leaders respond by rewarding them. The ties between leaders and followers are impersonal (Zondag 1999:54).

Authoritarian leadership is concerned mainly with the business in hand. The efficiency of the organisation enjoys preference, and relations are kept in the background. Inspirational leadership is mainly concerned 
with relations, although sight of the matter on hand is not lost. Relations are there to serve the interests of the work that has to be done, and this in turn furthers relations (Hendriks 1990:61). Integration of business and relations is the aim of inspirational leadership. Sensitivity to relations means treating other people with dignity and leaving room for their abilities, insights, views, attitudes, differences, creativity, emotions and actions. In a process of persuasion the other person and the interests of the business are taken into account. Co-operation between people and groups is promoted in that problems are examined together and solutions sought jointly (Hendriks 1990:63).

Inspirational leaders are usually more effective and have more goodwill towards their followers than impersonal leaders. Locke (Hendriks 1990:66) distinguishes three characteristics of inspirational leaders:

- Inspirational leaders have particular personal characteristics. They are driven, energetic, take initiative and have perseverance. Inspirational leaders also have the necessary knowledge and skills.

- Inspirational leaders are able to set goals, identify problems, analyse situations, solve difficulties and take decisions. Their approach is preeminently relational and they are good communicators. Inspirational leaders also have a vision.

- Inspirational leaders are able to design a perspective for the future. These leaders also demonstrate convincingly where the organisation or the social context of which they form part is headed. Leaders who inspire have a mission, a message.

The inspirational (co-operative) leadership style also demands competence of the leader. He or she must have intellectual and emotional intelligence. Such leaders also require a creative approach to conflicts and problem solving. People have to see that the leader is capable of visionary thought and action. Stimulating leadership embraces intention, competence and transparency (Hendriks 1990:66).

\subsection{Inspirational leadership from the perspective of the leader}

In the previous paragraph, in which inspirational leadership is described, we examined the role and functions of the leader. We shall now proceed to elaborate on this theme.

Leadership should be most likely to be inspirational if the leader regarded service as the nature of his or her task. With this approach, the leader regards and treats everyone with dignity. The leader, therefore, sees his or her task as taking care of both the business and relationships. 
This enables the leader to do justice to people as subjects (Luther 1992). Leadership as service means that the leader sees his or her task as supporting people and helping them to perform their task (Hendriks 1990:56).

There are at least two views on how leadership should be exercised. One view is that, in the final instance, the leader should take the decision, possibly in consultation with the rest of the group, either out of principle or for pragmatic reasons. The other view is that decisions should be taken by the people involved, and that the leader's task is to help the members of the group to reach a decision. Likert (1976) is an advocate of the last view. The "top group" is "not an executive committee making decisions for lower levels. Its role is to coordinate the decision making of all groups affected to assure the full involvement and participation of these groups" (Likert 1976:57). This does not mean, however, that decisions are invariably taken this way. This can only happen if the climate is favourable and the structure complies with certain conditions. The two views on the exercise of leadership should not be contrasted. The eader should consult his or her people in order to inform them about how decisions are being taken and, if possible, to take them along. Some decisions have to be taken without delay, however. Then the leader who is worth his or her salt and who enjoys the confidence of the group should have the courage and the space to take decisions. The leader should take the group into his or her confidence and inform them fully.

In contrast to the autocratic model, the inspirational model permits the sharing of power and authority. Power sharing means decentralisation, mainly because tasks and power have to be delegated. In this way, the members of an organisation are able to fulfil their own potential. Respect is also accorded to the individual's uniqueness, humanity and competence. This enables the individual to accept his or her responsibilities (Hendriks 1990:57). This style demands that the channels of communication should be and remain open. Informal and open communication is part of this style. The result of this style is that individuals find their work fulfilling. The leader who respects the individual, also receives respect. A leader should also be prepared to listen to other people. This demands willingness to communicate openly and honestly. This kind of leadership involves being approachable, having patience and compassion and allowing people to engage in dialogue, providing information, being fair and just, respecting the truth, putting a high premium on ethics (Hendriks 1990:58) and being open to constructive criticism.

Role-taking forms an integral part of leadership. Hans Alma (1998; 1999:96-98) distinguishes the following forms of role-taking: 
"Identifying role-taking. Whenever there is a strong bond with someone else, the individual tends to take over the other person's perspective. The reactions, values and judgments of the other person become the spectacles through which the person looks at himself or herself and assesses his or her own behaviour. The selfimage develops in tandem with the perspective of the conscious other. This identification may be regarded as the first step in the development of identity.

Role-taking from the point of view of a third party. In the further development of the child, he or she is exposed to numerous different and conflicting perspectives. This forces him or her to distinguish between role-taking and adopting the point of view of the other; in other words there is a distinction between role-taking and identification. This process is the foundation for the frames of reference which people make their own and which shape their actions."

A third type of role-taking can be distinguished. This is known as "synestic role-taking" (Lauer \& Broadman 1970/1971). "Synestic" comes from the Greek word sunesis, which means a running or flowing together; the faculty of comprehension, insight, understanding" (Lauer \& Broadman 1970/1971:147). This kind of role-taking is of great value in our consideration of leadership. Synestic role-taking represents an imaginative construction of the other person's perspective, which includes an understanding of feelings and experiences. "Synestic roletaking" creates an empathic relationship, in which cognitive understanding of the other person's experiential world is accompanied by emotional participation in that world. Sufficient distance should, however, be maintained between the person and the model (dependency relation). When prestige and exceptional gifts are ascribed to the other person, the follower's space is invaded and the proprietorship threatened. Role-taking then leads not to finding the person in relation to the other, but to the loss of the self in the idealised image which the leader represents. A delicate balance is required here. Identification figures could be moral and spiritual resources for the followers, by allowing central values to be expressed in their actions. They could enlarge the perspectives of their followers and show them new courses of action.

What do inspirational leaders give to their followers? Inspirational leaders give their followers ideals and enthusiasm and give them the freedom to be creative. Further, inspirational leaders give their groups self-confidence and a feeling of self-worth (Koopman \& House 1995). They reinforce authenticity (the correspondence between opinions and 
behaviour) in their followers. The leaders succeed in getting others to believe in a better future, and reinforce the collective identity of an organisation or group (Zondag 1999:55). Inspirational leaders not only confer confidence, but also receive it. Confidence helps to build credibility, which is the basis for the success of an organisation (Podsakoff et al 1990). Inspirational leaders also succeed in boosting the loyalty and commitment of their groups (Tiche \& Devanna 1990). These leaders reinforce affective commitment in particular. There is a question of affective commitment when people feel that they are intrinsically attached to and identify with what they are doing, and derive pride from their achievements (Allen \& Meyer 1990: 1996; 1997; Zondag 1999:55). With regard to affective commitment, we can distinguish between continuity commitment and normative commitment. With continuity commitment the tie is of an impersonal nature. We speak of normative commitment when fidelity and duty are the basis for the bond (Zondag 1999:55).

An inspirational leader cannot live without humour and selfrelativisation (Stoffels 1999:86). Such leaders must learn not to take themselves too seriously.

\subsection{Inspirational leadership from the perspective of the group}

Behling and McFillen (1996), two management experts, developed a model of charismatic/transformational leadership. Their intention was to define the typical characteristics of this style of leadership more sharply. This enabled them to develop investigative tools, as well in order to determine to what extent this type of leadership was present or absent in an organisation (Van der Lans 1999:88). This also creates opportunities for self-evaluation, in that from time to time the leaders can measure their own performance by these standards.

It is striking that Behling and McFillen begin with a description of the characteristics not of the leader but of the followers. The attitudes, practices and actions of the followers make it apparent whether charismatic leadership is being practised (Van der Lans 1999:88). Three qualities can be distinguished among employees (subordinates, colleagues):

- Engagement. There is a high degree of involvement in the work. Further, the employees are convinced of the moral value of the aim of the organisation, and find it worth while giving themselves to the organisation.

- Respect for and confidence in the leader, and in the correctness of his service policy. The employees are also convinced of the reliability of 
the leader's judgment and vision and are prepared to follow the course that is set.

- Confidence in own abilities. The employees show evidence of a sense of personal worth. They believe in themselves and in their ability to achieve the goals of the organisation.

Through a combination of these three qualities, the group is able to make a special effort, they feel an involvement in the welfare of the organisation and they are prepared to put their personal interests aside.

These three qualities within the group are the fruit of the qualities of the leader. Involvement in the activities of the organisation is fed by the leader's empathy. The leader shows empathy with the needs of the group and an awareness of the tensions to which they are subject.

Two further qualities in the leader invite respect and confidence. Self-assurance. By the nature of actions the leader makes it clear that he or she knows what he wants to do and has confidence in the possibility of achieving his goal. He is prepared to tackle and remove any obstacles in his path. This also characterises his attitude towards his colleagues. If the leader accepts his colleagues the way they are and shows confidence in them, this creates the impression that he is sure of himself. Competence. The way in which the leader tackles and carries out his task creates the impression that he is an expert, has things under control and is devoting himself to his duties.

The group's feeling of self-worth and self-confidence is reinforced when the leader makes it clear that he has high expectations of his colleagues and gives them the feeling that he is capable of solving problems and creating opportunities for success. To be able to do this, the leader has to set goals that are realistic and achievable, encourage and support his people and allow them to participate in managerial responsibilities.

\subsection{Leadership climate, structure, goals and tasks}

The quality of an organisation is determined by the shaping of the climate, the structure and the quality of the goals and tasks.

Organisations differ in respect of their climate. A healthy climate is conducive to inspirational leadership and a vital organisation (Hendriks 1990:41-42). A healthy climate is created and sustained when people as subjects are given the space to accept their responsibilities and freedoms. This helps to create a climate of confidence, involvement and activity.

Leadership makes high demands on the structure of the organisation. The structure should not reinforce power and dominance but should instead give people the space to perform their tasks effect- 
ively. This means that the function of structures is to serve and support the people.

Inspirational leadership is carried by an organic system. In such a system tasks are seen and assessed in the light of the interests and goals of the entire organisation. In concrete terms, this means that coordination takes place through mutual communication, tasks are fluid and can change if necessary, and communication takes place at all levels (Hendriks 1990:59), especially through actions. "Finding out how to cook and how to work with others is something that comes with doing it..." (Sher 1999:53). Duties are determined jointly by information and advice from the leader; loyalty to the enterprise and to people is of the utmost importance; communal values and goals determine the team spirit and drive of the organisation; the leader is not the only specialist, and in fact the group depend on one another in respect of expertise (see Burns \& Stalker 1968; Hendriks 1990:60).

Purpose nvolves understanding what the goals are. A task is a job that a person or a group has taken upon himself or itself. A task implies that there is an intention to accomplish something - a goal. The goal has to be realised, and this leads to the formulation of tasks. In respect of the goal, the question is to what extent it manifests itself, and is concrete, communal and inspirational. With tasks the extent to which they give people the opportunity to behave as subjects plays a significant role (Hendriks 1990:122).

A leader must have the courage to act and to persevere. Leadership demands hard work. Blaise Pascal (1623-1662), the French mathematician who invented the pocket calculator, designed fifty pocket calculators before his patent succeeded, to give one example, and Ludwig van Beethoven rewrote his 5th Symphony fourteen times.

\subsection{Leadership and identity}

By "identity" Hendriks (1990:140) understands the self-definition of a group in which a group expresses what they see as the characteristic and distinctive features of their culture and society. This implies that the identity concept is developed in interaction with society. This concept is not fixed for all time, but changes in the course of time. It is indissolubly linked to the changes to which the group is exposed, and also to the changes to which the culture and society is subject (Hendriks 1990:140141). The challenge is to give the concept relevant and meaningful content in the light of all the changes. 


\subsection{Autocratic leadership}

In the case of autocratic leadership there is little communication from the top to the bottom, little openness and a lack of joint consultation about aims. A negative climate results, and little inspirational leadership.

The focus of an autocratic style is the emphasis on the authority of the leader. A particular style of leadership is influenced by the nature of the relations between the leader and the members. Distance and dominance expressed both in attitudes and in actions are all characteristic of the authoritarian style of leadership.

There are various devices which the leader can apply as techniques of leadership. In the authoritarian leadership style the following are the main techniques used: the authority of the leader's position; encouragement in the form of tangible incentives; the idealisation of the tasks and the advancement of rational arguments. The various techniques which leaders use are designed to appeal to different motives among the group. The emphasis on authority is mainly an indication of the weight attached to the position of leader and appeals to obedience. The promise of rewards is directed to the acquisitive drive, and - I should add - to the drive for recognition and prestige. The rational arguments appeal mainly to insight and co-responsibility. It should be remembered that rational arguments can also play an important part in inspirational leadership. Arguments are only co-ercive if they are used in an overbearing manner. This fits in with the authoritarian style. In the inspirational style arguments are used persuasively. In this case they appeal to the intellectual and emotional reasonableness of the person. The person is recognised and valued as a subject.

The attitude of the leader towards the members also helps determine the leadership style. The authoritarian leader likes followers and appreciates obedience and discipline. The people subjected to an authoritarian style usually find that they are not understood and may even find the style of leadership oppressive. The climate of authoritarian leadership is usually tense and mistrustful.

Autocratic leadership is supported by a mechanical system. This means that information is sent upwards and instructions downwards. Loyalty and obedience are the preconditions in an organisation of this kind. Co-operation and control are created by a hierarchical authoritarian structure. Competence is also assessed hierarchically.

\section{IMAGINATIVE LEADERSHIP}

"Society often forgives the criminal. It never forgives the dreamer" (Oscar Wilde). Leaders need to make time to dream; to dream in another key. Even if he is not ready for tomorrow, a leader must be able to dream 
about tomorrow. A dream about tomorrow creates the possibility of a different reality from today.

A dream creates a space for imagination. Imagination is not something that can be taken for granted. To be able to think imaginatively demands more of a leader than to function in everyday life. Schuman (1998:50) says that without imagination we don't get anywhere, because we are rudderless.

When one looks with the eye of the imagination, one gains a real sense of presence, encouragement and trust (Jongsma-Tielema 1998:59). The reason is that the eyes of the imagination enable us to look beyond the immediate reality.

In this regard, we can refer to a model of change which was developed by Watzlawick, Weakland and Fisch (Watzlawick et al 1974) on the basis of the Group Theory of the French mathematician Évariste Galois, and the linguistic games of Wittgenstein, as contained in his Philosophische Untersuchungen (Wittgenstein 1958). The model is highly relevant, in that it attempts to introduce a new manner of looking at social or personal conflicts or "games" and so to end futile conflicts or "games without end" in which a society, an organisation, a family or an individual can be caught up (see Garratt 2000:16-24).

The essential distinction of the model of change under discussion is between change of the first order and change of the second order. It is characteristic of change of the first order that the solution usually becomes the new problem.

Watzlawick et al use the analogy of a nightmare to illustrate the difference between the two kinds of change. Someone who is having a bad dream can do various things, such as run away, hide, fight, scream, jump off a cliff, etcetera, but none of these actions (that is of the first order) will ever end the nightmare. The only way to end the nightmare is through a second-order change, namely to wake up and so to pass into a completely different state (Watzlawick et al 1974:10). Second order change is also known as change of change, just as acceleration is the movement of movement.

The nature of second-order change is usually paradoxical. Sometimes the solution to a problem involves doing nothing, in other words, not attempting to bring about any change, but usually it is necessary to step outside the prevailing logic in a creative leap. Second-order change usually also involves acting in a crisis. A crisis is an onslaught on people's hope and confidence. Inspirational leadership really comes into its own in times of crisis. One characteristic of a crisis is that the conventional solutions to problems fail. Through their vision inspirational leaders embody new hope and confidence (Zondag 1999:55). 
In such circumstances inspirational leaders can seek and find a way out of the crisis. They look for another perspective on the future. Prokofiev was ill and could not attend the performance of his inspiring First Piano Sonata which was being played by somebody else. He listened to it over the telephone (Carson 1998:20). Imagination means finding another way out, despite restrictions. If I cannot listen in person I can listen over a telephone.

One example which Watzlawick et al (1974:xi) quote is that of an Austrian castle in the $14^{\text {th }}$ century that was under siege, the only food left being one ox and two bags of grain. Once that had been eaten they faced the prospect of starvation and eventual conquest by the besieging army. The proposed solution was that they should slaughter the ox, sew up the grain in it and throw it to the enemy over the wall. This flamboyant act was interpreted by the Duchess Margareta Maultasch as a sign of the abundance of food supplies inside the castle and she immediately ended the siege and departed.

One could give many similar examples of the "strange" and logically paradoxical nature of second-order change, especially in the domains of fine art, scientific breakthroughs or the cure of long-standing phobias or behavioural problems in people. To sum up, one could say the following:

- Second-order change is applied to what is seen as a solution from the perspective of first-order change, while the solution is usually the core of the problem.

- While first-order change is based on common sense - "more of the same medicine" - second-order change appears strange, unexpected and enigmatic.

- Applying second-order change techniques to the "solution" means that one is dealing with the problem here and now. These techniques are applied to the consequences and not to the supposed causes (like the 300 years' history), the important question is "what?" and not "why?" (Adapted from Watzlawick et al 1974:83).

- The circular reasoning of the first-order "solution" - which remains within the same logic as the problem itself - is broken and the problem is restructured.

In times of crisis followers are susceptible to the appeal which energetic people, with strong relational and rational skills, make to them (Zondag 1999:55). 


\section{LEADERSHIP AS A KEY}

The community of faith and society both have a life-long need for inspirational leadership. It is inspirational leadership that opens up the future - the dream of a promised land. With inspirational leaders the journey is a joy, even if there are obstacles in the path.

\section{Consulted literature}

Allen, N J \& Meyer, J P 1990. The measurement of antecedents of affective, continuance and normative commitment to the organisation Journal of Occupational Psychology 63: 1-18.

-, 1996. Affective, continuance and normative commitment to the Organisation. Journal of Vocational Behavior 49: 252-276.

-, 1997. Commitment to the workplace. Thousand Oaks: Sage Publications.

Alma, H A 1998. Identiteit door verbondenheid: Een godsdienstpsychologisch onderzoek naar identificatie en christelijk geloof. Kampen: Kok.

-, 1999. Identificatie en charismatisch leiderschap. Praktische Theologie 26(4): 479 - 487.

Andriessen, J H \& Drenth, P J 1997. Leiderschap in organisatie, in: Drenth, P J; Thierry, H \& de Wolff, C J (reds). Nieuw handboek arbeids- en organisatiepsychologie, 857-911. Houten: Bohn Stafleu Van Loghum.

Barnes, D F 1978. Charisma and Religious leadership: an historical analysis. Journal for the Scientific Study of Religion 17(1): 1-18.

Bass, B M 1985. Leadership and performance beyond expectations. New York: Free Press.

Behling, O \& McFillen, J M 1996. A syncretical model of charismatic / transformational leadership. Group and Organisation Management 21(2): 163191.

Bryman, A 1992. Charisma and leadership in organisations. London: Sage.

Burns, T \& Stalker, G M 1968. The Management of Innovation. London: Tavistock Publications.

Carson, A 1998. Short Talks. London, Ontario: Brick Books.

Den Hartog, D H, Koopman, P L \& Van Muijen, J J 1997. Inspirerend leiderschap in organisaties. Schoonhoven: Academic Service.

Eisenstadt, S N (ed) 1968. Max Weber on charisma and institution building: selected papers. Chicago: University of Chicago Press.

Garratt, B 2000. The Learning Organisation. Developing Democracy at Work. London: Harper Collins Publishers.

Hendriks, J 1990. Een vitale en aantrekkelijke gemeente. Model en methode van gemeente opbouw. Kampen: Kok.

Jongsma-Tielema, P E 1998. Godsdiens als speelruimte voor verbeelding. Gereformeerd theologisch tijdschrift 2: $57-66$.

Koopman, P L \& House, R J 1995. Charismatisch leiderschap in organisaties, in: Van der Vlist, R, Steensma, H, Kamperman, A \& Gerrichhausen, J (red). Handboek leiderschap in arbeidsorganisaties, 39-54. Utrecht: Lemma.

Kotter, J P 1996. Leading Change. Boston : Harvard Business School Press.

Lauer, R H \& Boardman, L (1970/1971). Role-taking: theory, typology, and propositions. Sociology and Social Research 55: 137-148. 
Likert, Rensis \& Likert, Jane Gibson Liert 1976. New ways of managing conflict. New York: Mc Graw - Hill.

Luther, H 1992. Religion und Alltag. Bausteine zu einer Praktischen Theologie des Subjekts. Stuttgart: Radius Verlag.

Podsakoff, P M, Mackenzie, S B, Moorman, R H \& Fetter, R 1990. Transformational leader behaviors and their effects on followers' trust in leader, satisfaction and organisational citizenship behavior. Leadership Quarterly 2: 107-142.

Remmerswaal, J 1975. Inleiding tot de groepsdynamika. Bloemendaal: Nelissen.

Schuman, N 1998. Vertakkingen, in: Oskamp, P en Schuman, N (eindredakteurs). De weg van de liturgie. Tradities, achtergronden, praktijk, 39 - 51. Zoetermeer: Meinema.

Sher, G 1999. One Continuous Mistake. Four Noble Truths for Writers. Penguin: New York.

Stoffels, H 1999. Soms kom ik als een hartelijk mens over. Praktische Theologie 26(4): 451-470.

Tiche, N M \& Devanna, M A 1990. The transformational leader. New York: Wiley.

Van der Lans, J 1999. Een model voor charismatisch leiderschap. Praktische Theologie 26(4): 471-478.

Watzlawick, P, Weakland, J H and Fisch, R 1974. Change - principles of problem formation and problem resolution. New York: Norton \& Co.

Wittgenstein, L 1958. Philosophische Untersuchungen, English translation by Anscombe, GEM. Oxford: Blackwell.

Zondag, H 1999. Bezielen, veranderen en daadkracht. Katholieke pastores en inspirerend Leiderschap. Praktische Theologie 26(4); 438-450. 